\title{
ПРОБЛЕМА ДОМЕСТИКАЦИИ ЛОШАДИ НА БЛИЖНЕМ ВОСТОКЕ В ІІІ ТЫС. ДО Н.Э.
}

\author{
Станислав Аркадьевич Григорьев \\ Институт истории и археологии УрО РАН, Челябинск, Россия \\ E-mail: stgrig@mail.ru
}

\begin{abstract}
Аннотация. В настоящее время принято считать, что лошадь была одомашнена в степной Евразии в энеолите или раннем бронзовом веке, в IV-IIIтыс. дон.э. В действительности, реальные данные о домашней лошади в степи появляются только в начале II тыс. дон.э. Доместикация лошади - это очень сложный процесс, требующий специфических условий, обусловленных социально-экономическими причинами (содержание в неволе несколько поколений с осуществлением целенаправленной селекции). Последующее содержание лошади тоже сложнее, чем содержание крупного и мелкого рогатого скота. Оно имело смысл лишь тогда, когда была необходимость в использовании специфических преимуществ лошади перед этими видами. Такие причины и условия сложились к началу III тыс. дон.э. на Ближнем Востоке: развитая торговля, развитие транспортных средств, наличие элиты и использование разных видов эквидов. Первоначальным мотивом для доместикации лошади в этом регионе было использование диких лошадей для производства мулов. Самостоятельное значение коневодство получает лишь с распространением легких одноосных повозок. Этот процесс хорошо отражен в нескольких независимых друг от друга группах источников: остеологических останках, иконографии, письменных документах. Вероятно, на Ближнем Востоке плейстоценовая лошадь сохраняется только в Анатолии, и ее ранние находки маркируют охоту на дикий вид. В VI-IV тыс. дон.э. находки костей лошади появляются в других ареалах этого региона и известны единичные признаки доместикации. Однако более надежные данные возникают не ранее середины ІІІтыс. дон.э.
\end{abstract}

Ключевые слова: доместикация, лошадь, Ближний Восток, социально-экономические условия, III тыс. до н.э.

Цитирование. Григорьев С.А., 2021. Проблема доместикации лошади на Ближнем Востоке в III тыс. до н.э. // Уфимский археологический вестник. Т.21, №2. С.222-238. DOI: https://doi.org/10.31833/ uav/2021.21.2.004

UDC 902(5)

Submitted: 21.06 .2021

LBC 63.4(5)

Accepted: 22.10 .2021

\section{THE PROBLEM OF HORSE DOMESTICATION IN THE NEAR EAST IN THE 3rd MILLENNIUM BC}

\author{
Stanislav A. Grigoriev \\ Institute of History and Archaeology of the Ural Branch of the RAS, Chelyabinsk, Russia \\ E-mail: stgrig@mail.ru
}

\begin{abstract}
It is now generally accepted that horses were domesticated in steppe Eurasia in the Chalcolithic or the Early Bronze Age, in the $4^{\text {th }}-3^{\text {rd }}$ millennia BC. In fact, the real evidence of horse herding in the steppe region appears only at the beginning of the $2^{\text {nd }}$ millennium $\mathrm{BC}$. Horse domestication is a very complex process that requires highly specific conditions determined by the socio-economic reasons. To breed a domestic individual, horses must be kept in captivity for several generations and targetly selected throughout the whole period. The subsequent herding of horses is also more difficult than the herding of cattle, goats and sheep. Therefore, it made sense only when there was a need to use particular advantages of the horse over these species. Such a need arose by the beginning of the $3^{\text {rd }}$ millennium BC in the Near East in the view of advanced socio-economic conditions: well-developed trade, active development of the means of transport, the presence of elite and the availability of different types of equines. The initial stage of horse domestication in this region was determined by the involvement of these animals in the production of mules. Horse breeding obtained its independent significance only with the spread of light two-wheeled carts. This evidence is supported by several independent groups of sources: osteological remains, iconography, written documents. In the Near East, the Pleistocene horse probably preserved only in Anatolia, its finds, thus, mark the hunting for wild species. In the $6^{\text {th }}-4^{\text {th }}$ millennia $\mathrm{BC}$, finds of horse bones appear in other areas of this region. Although some scholars estimate horse domestication began in those eras, the more reliable data does not appear until the middle of the $3^{\text {rd }}$ millennium BC.
\end{abstract}


Keywords: domestication, horse, Near East, socio-economic conditions, $3^{\text {rd }}$ millennium BC

Citation. Grigoriev S., 2021. The problem of horse domestication in the Near East in the $3^{\text {rd }}$ millennium BC. Ufimskij arkheologicheskiy vestnik [The Ufa Archaeological Herald]. Vol. 21, no. 2, pp. 222-238. (In Russ.). DOI: https://doi.org/10.31833/uav/2021.21.2.004

\section{Введение}

Одной из популярнейших тем в древней истории является проблема одомашнивания лошади. Популярность ее обусловлена связью с проблемами изобретения колесницы и распространения индоевропейцев в Евразии. В настоящее время доминирующей точкой зрения является локализация прародины индоевропейцев в Понто-Каспийских степях, и считается, что внедрение этих новшеств произошло в энеолите или бронзовом веке этого региона. В основе этого лежит мнение, что широкое распространение диких лошадей в Восточной Европе способствовало их доместикации. Обнаружение большого количества лошадей на энеолитических поселениях Дереивка на Украине и Ботай в Казахстане сформировало идеи, что уже в то время в степи появляется одомашненная лошадь, а вскоре идеи об использовании этой лошади для верховой езды. Последнее было обусловлено ошибочной трактовкой роговых предметов из Дереивки в качестве псалиев [Телегин, 1973] и выявлением стертости от удил на зубах одного из черепов, который, как позже выяснилось, относится к раннему железному веку [Anthony et al., 2006. P. 137]. Затем были выявлены следы стертости от удил на зубах некоторых лошадей с поселений Ботай и Кожай, а также следы навоза в жилищах Ботая. Ввиду отсутствия данных о колесном транспорте, был сделан вывод об использовании лошади под верховую езду [Anthony et al., 2006. P. 145, 147]. Появились также работы, предполагающие доместикацию лошади в степной зоне еще в неолите, но подкрепляется это лишь косвенными данными: наличием костей лошади, в том числе в составе жертвенников, и присутствием скульптурных изображений лошадей [Наумов, 2008; Юдин, 2008]. В целом, эти представления широко распространены и глубоко укоренились среди археологов, хотя сомнения и возражения имели место всегда.
В основе этих сомнений лежат биологические особенности лошади. В отличие от иных животных, морфология ее скелета не позволяет отличить дикий вид от домашнего. По сути дела, единственным аргументом в пользу домашней лошади на Дереивке являются ее меньшие размеры по сравнению с диким видом [Котова, 2013. С. 120]. Уменьшение размеров вида при доместикации действительно происходит, но это не касается лошадей, которые изменяются быстро в новых условиях независимо от этого. Фиксация стертости зубов некоторых особей тоже не всегда указывает на использование удил, так как может объясняться неправильным прикусом [Levine, 2005. P.11; Косинцев, 2008. С. 116, 117]. Подобные следы на втором премоляре были выявлены у плейстоценовой лошади из Северной Америки [Olsen, 2006]. Последние исследования и сопоставления этих следов на зубах ботайских лошадей и лошадей Северной Америки, а также обобщение всех прочих данных позволяет с полной гарантией утверждать, что ботайская лошадь была дикой [Taylor, Barrón-Ortiz, 2021]. ${ }^{1}$ Любые изображения, как и палеолитические изображения лошадей, тоже не являются свидетельством доместикации. Однако, и в более позднее время РБВ и СБВ ${ }^{2}$ свидетельства о наличии в степи домашних лошадей отсутствуют, даже такие неоднозначные, как стертости на зубах.

Первые надежные данные о домашней лошади появляются в начале IIтыс. дон.э. (кал.) $)^{3}$ в колесничных погребениях синташтинской культуры в Зауралье. В целом, это близко по времени данным о домашней лошади Ближнего Востока. Однако, возможности доместикации в последнем регионе даже не обсуждаются, и присутствие там лошадей объясняется импортом из степной Евразии [Anthony et al., 2006. Р. 147; Shev, 2016. Р. 127, 128]. Поэтому задачей этой статьи является рассмотрение объективных данных, указывающих на доместикацию лошади в разных регионах.

\footnotetext{
${ }^{1}$ Весьма показательной является статья сторонников гипотезы об одомашненной лошади в энеолите Казахстана С.С.Калиевой и В.Н.Логвина [2011] в которой они собрали все возможные аргументы в пользу отстаиваемой позиции. Бросается в глаза полное отсутствие прямых аргументов и использование любых косвенных, непризнание логики и фактов противников этой гипотезы, использование однотипных фактов для противоположных выводов (напр. в случае со структурой стада), фактов, не имеющих отношения к проблеме (наличие трех медных изделий) и т.д. Эта статья прекрасно показывает, что надежных фактов доместикации энеолитической лошади нет.

${ }^{2}$ В статье использованы сокращения: МВ - медный век; РБВ - ранний бронзовый век; СБВ - средний бронзовый век; ПБВ - поздний бронзовый век; РД - Раннединастический период.

${ }^{3}$ Существует заметная разница в радиоуглеродных калиброванных датах и исторической хронологии Ближнего Востока. Это стало причиной представлений о том, что ближневосточные колесницы моложе степных. В действительности, они имеют более ранние даты, поскольку начало синташтинской культуры в радиоуглеродных датах относится к XX в. до н.э., а в исторической хронологии - к середине XVIII в. до н.э. [Григорьев, 2020]. В этой работе при обсуждении материалов Ближнего Востока будут использоваться даты в системе «средней» хронологии Месопотамии. Избежать использования радиоуглеродных дат не удастся, поэтому чтобы в каждом случае не разъяснять их употребление, это будет отмечено, например, 2050 г. до н.э. (кал.).
} 


\section{Зооархеологичские и палеогенетические признаки доместикации}

Из-за отсутствия возможности идентифицировать домашнюю лошадь на основании морфологии скелета, единственным способом является анализ больших коллекций костей, и для Дереивки и Ботая этот анализ выявил картину, характерную для массового забоя лошадей в ходе охоты: наличие сочлененных частей скелета, что немыслимо для скотоводов, и соответствующие дикому стаду соотношения животных разного возраста и пола [Levine, 2005. Р. 14; Косинцев, 2008. С. 118, 119]. Поэтому энеолитическая лошадь была дикой. Однако для лошадей III тыс. дон.э. в степной зоне Восточной Европы провести подобный анализ не представляется возможным из-за отсутствия больших коллекций костей.

В последние годы появились идеи о том, что лошадь была доместицирована в Европе в IIIтыс. до н.э. Признаком этого служит рост доли лошадей в костных остатках на памятниках культуры шаровидных амфор [Czebreszuk et al., 2008. P. 48]. Но это можно объяснить увеличением охоты на лошадей или заимствованием домашних лошадей из ямной среды с востока. То есть, строгих фактов доместикации в этом регионе тоже нет.

Определенные надежды дают палеогенетические исследования костей, но они в самом начале пути, больших статистически достоверных серий пока мало, и далеко не все районы охвачены этими исследованиями. Очень часто выводы делаются на основании данных о современной популяции лошади. Но самые существенные изменения генетических пулов, которые привели к современному состоянию, начались около 900 г. до н.э. и наибольший вклад в современную популяцию внесли лошади Восточной Европы и Западной Сибири, и это результат поздних изменений, ничего не говорящий о месте первичной доместикации [Benecke, 2018. P. 69; Fages et al., 2019]. Последняя работа по этой теме показала, что современная популяция домашних лошадей ведет свое начало от лошади IV-III тыс. дон.э. (кал.) волго-донских степей, но активное распространение этого генетического профиля за пределы данного ареала происходит после 2000 г. дон.э. (кал.) [Librado et al., 2021]. Следует отметить, что не существует какого-то гена, который указал бы на доместикацию. Поэтому палеогенетика предоставляет лишь косвенные данные, нуждающиеся в интерпретации. Тем не менее, эти исследования показали, что современные домашние лошади своим происхождением не связаны с лошадью Пржевальского [Jansen et al., 2002; Lindgren et al., 2004. Р. 336], а последняя является потомком ботайской лошади [Gaunitz et al., 2018]. Соответственно, ботайская лошадь, скорее всего, не участвовала в процессе доместикации. Необходимость осторожного подхода к этому вопросу обусловлена тем, что, строго говоря, эти данные указывают лишь на то, что эти лошади не приняли участие в формировании популяции современных лошадей.
Кроме того, генетические исследования позволяют определить окрас. В Евразийских степях вариабельность окраса лошадей появляется после 3000 г. дон.э., что рассматривается как признак доместикации, а для Центральной Европы такие данные появляются в период 3370 и 3100 гг. до н.э. (кал.) [Benecke, 2018. Р. 65]. Но в этом случае мы имеем дополнительный факт в пользу отсутствия данных о доместикации в энеолите и возможность эпизодического присутствия домашних лошадей в бронзовом веке. Однако эти результаты получены на небольших сериях, и мы можем допустить какие-то чисто биологические причины появления этой вариабельности. То есть, это является признаком, но не безусловным признаком. Сомнения в наличии одомашненной лошади в РБВ Восточной и Центральной Европы подкрепляются тем, что лошади, связанные с европейскими шнуровыми культурами, не демонстрируют генетического профиля, характерного для волго-донских предков домашних лошадей, из чего делается вывод о том, что ямники в Европу мигрировали без лошадей [Librado et al., 2021. P. 5].

Ранее на основании палеогенетических данных предполагалось, что предками первых домашних лошадей Евразии были лошади бронзового века Юго-Восточной и Восточной Европы и Закавказья, но в основном процесс формирования современной популяции лошадей происходил в раннем железном веке [Benecke, 2018. Р. 69]. Это допускает несколько центров доместикации. Последние данные указывают на то, что предками современных лошадей были, преимущественно, лошади Восточной Европы, и их распространение в иные регионы началось около 2000 г. до н.э. (кал.), что связывают с синташтинской культурой и ее колесничным комплексом, но более раннее их распространение объясняют распространением всадничества с 2200 г. дон.э. (кал.) [Librado et al., 2021. Р.5]. Но в случае первичной доместикации в каком-то одном регионе и распространения коневодства в иные, в состав домашних табунов могли включать местных диких лошадей, что и дало эту картину. Подобная возможность включения диких лошадей в домашние табуны обсуждалась археозоологами [Levine, 2005. Р. 19]. В этом случае палеогенетические исследования обязательно покажут присутствие местных генетических линий, но это не означает, что коневодство как феномен формировалось именно в этом регионе. После миграций относительно небольшого синташтинского коллектива и распространения коневодства на все степные популяции, включение в домашние табуны диких особей было неизбежно.

Последние генетические исследования показали, что основой популяции домашних лошадей Малой Азии не были местные особи. Основным гаплотипом становится Q, который ранее присутствовал на Южном Кавказе. Однако с 2200 г. дон.э. (кал.) в обоих этих регионах появляется серия иных гаплотипов, из чего делается вывод, что только с этого времени можно говорить о до- 
местикации, и эти новые группы лошадей пришли из степной Евразии [Guimaraes et al., 2020]. Строго говоря, это показывает лишь то, что доместикация не произошла в Малой Азии, но Южный Кавказ или Восточная Анатолия остаются вполне приемлемым кандидатом. К сожалению, в последнюю работу по палеогенетике лошадей материалы из этих регионов включены не были, и было показано, что анатолийская неолитическая лошадь не являлась предком современной домашней лошади, но лошади с пос. Ачемхёюк с датами 2200-2040 и 1970-1870 гг. до н.э. (кал.) имеют тот же генетический профиль и сопоставимы с доно-волжскими лошадьми. Предполагается, что эти лошади в это время появились там, а также в Карпатском бассейне (пос. Холубице и Гординешти II), из степной Евразии еще до изобретения колесниц [Librado et al., 2021. P. 3, 5. Suppl. materials] и за 200 лет до надежно зафиксированных домашних лошадей синташтинской культуры. В действительности, данные о колесничестве на Ближнем Востоке и в Карпатах предшествуют синташтинской культуpe, и ложатся в этот хронологический горизонт; в Карпатах, при этом, появляется ближневосточный тип колесниц [Григорьев 2020; Grigoriev, 2021]. Поэтому мы можем констатировать, что данные об одомашненной лошади везде хронологически совпадают с данными об использовании колесниц. Генетическое же сходство этих лошадей может объясняться более ранней генетической близостью лошадей Закавказья и Восточной Европы.

\section{Биологические и социально-}

\section{экономические условия доместикации}

Существуют биологические особенности лошади, которые необходимо учитывать, обсуждая проблему ее доместикации, под которой следует понимать не приручение отдельных особей, а получение популяции животных, которые по своей воле остаются с человеком на протяжении поколений. Лошадь - очень проблемное животное для одомашнивания. Примером являются неудачные попытки приручения лошади Пржевальского. Поведение лошади, даже аллюр, зависит от генов. Поэтому формирование нужных психологических, поведенческих и физиологических типов требует длительного процесса селекции, то есть содержания табуна диких лошадей в неволе на протяжении нескольких поколений [Levine, 2005. P. 11, 16, 17, 19; Benecke, 2018. Р. 67, 68]. Причем, люди, которые собрались заняться этим, должны иметь конкретную цель, которой им следовало достигнуть, и добиваться ее на протяжении нескольких поколений лошадей. То есть, эта цель должна быть четко сформулированной и настолько значимой, что общество готово было нести огромные материальные и физические расходы на содержание табуна лошадей в течение десятков лет. Это практически исключено для охотников Ботая. Охотники вообще не приручают животных; исключением являются собака и северный олень. Причина этого, в первую очередь, в сезонном характере успешной добычи. Поэтому существова- ли сезоны дефицита продуктов, и попытки создать небольшое стадо заканчивались бы его периодическим поеданием. Не было очевидных причин для преодоления этих трудностей и в скотоводческих обществах IV-III тыс. дон.э. (кал.) Восточной Европы, которые все проблемы с мясом, молоком и шерстью решали разведением крупного рогатого скота и овец, и было проще нарастить их поголовье, чем одомашнивать новый вид. Но даже если бы это удалось сделать, последующее содержание лошади гораздо сложнее, чем содержание овец и коров. Соответственно, необходимы специфические условия, при которых качества лошади оказываются выигрышными на фоне привычных домашних видов. Единственным таким качеством является ее способность везти человека в повозке или верхом с относительно высокой скоростью. Но лошадь нельзя запрячь в тяжелую повозку бронзового века с массивными колесами, которую тащили быки. Поэтому не случайно, надежные данные о домашних лошадях появляются вместе с легкими двуколками со спицами или колесницами на рубеже III и IIтыс. дон.э. Значит ли это, что в степной Евразии должна была появиться идея легкой повозки и с этой целью в течение длительного времени люди занимались столь сложным процессом доместикации? Поскольку такой вариант не представляется реальным, было высказано предположение, что первоначально лошади были одомашнены для получения мяса, и длительное время так и использовались. Но с появлением колесниц, они стали упряжными животными [Drews, 2017. P. 33, 36, 37, 39]. Тогда возникает новая проблема, так как подобные животные должны были быть тучными, спокойными и медлительными. Они не годились для запряжки в колесницы и было необходимо производить новую селекционную работу. Более вероятно, что лошадь для запряжки в колесницу была выведена из дикого вида.

Во всей последующей человеческой истории оседлые общества держали лошадь исключительно для транспортных и военных целей, и, как правило, никогда не употребляли ее в пищу и не пили лошадиное молоко. Это практиковали лишь кочевники, у которых лошадь выполняла также вспомогательную функцию сбивания верхнего наста при тебеневке, что облегчало выпас остального стада. Но главной функцией лошади в кочевых обществах были транспортная и военная. Поэтому до начала IІтыс. до н.э. (кал.) на юге Восточной Европы отсутствуют как однозначные свидетельства ее доместикации, так и условия, необходимые для этого. Гипотетически мы можем допустить генетические отклонения у каких-то особей, которые позволяли их приручить, но это не является социально-экономическим феноменом, который является предметом нашего обсуждения.

Социально-экономические условия доместикации лошади на Ближнем Востоке

Единственным районом, где есть факты доместикации и была потребность в ней, является Ближний Восток с его сложно устроенным хо- 
зяйством, высокоразвитым обществом, широкой сетью коммуникаций и использованием эквидов в транспортных целях. На первом месте в этом списке факторов стоит торговля. Успехи сельскохозяйственного развития Месопотамии привели к резкому росту потребностей в иных ресурсах, которых Месопотамия была лишена, в первую очередь, металлов. Оценить изменения в объемах этой торговли мы можем на основе огромного массива данных, собранных для Ближнего Востока

Л.И.Авиловой. Эти данные суммированы в двух таблицах (табл. 1; 2). Раннединастический период Месопотамии рассматривается в этой работе, преимущественно, в рамках СБВ. ${ }^{4}$ Соответственно, медный век датируется V тыс. дон.э. (кал.), РБВ - IV тыс. до н.э. (кал.) - первая половина III тыс. дон.э. (кал.) и СБВ - вторая половина III тыс. до н.э. - XVIII в. до н.э. [Авилова, 2008. С. 74, 134141].

Таблица 1

Количество находок металла в разных районах Ближнего Востока

Table 1

The number of metal finds in different areas of the Near East region

\begin{tabular}{|c|c|c|c|}
\hline & МВ & РБВ & СБВ \\
\hline Анатолия & 71 & 360 & 36586 \\
\hline Месопотамия & 6 & 580 & 14307 \\
\hline Левант & 4 & 701 & 4795 \\
\hline Иран & 160 & 952 & 2174 \\
\hline
\end{tabular}

Из таблицы 1 мы видим взрывной рост потребления металла при переходе к каждой новой археологической эпохе. Особенно значителен он при переходе РБВ/СБВ, возрастая в Анатолии в 10 ра3, а в Месопотамии - в 24,6 раза. Реальный рост объемов был, конечно, намного больше, так как вес изделий тоже увеличивался. Анатолия была основным источником меди для Месопотамии, но в СБВ происходят и иные перемены: заметную долю в металле начинают занимать оловянные бронзы (табл.2), а олово доставлялось с востока через перевалы Загроса.

Типы сплавов в разных районах Ближнего Востока (по: [Авилова, 2008])

Types of alloys in different areas of the Near East region (after: [Avilova, 2008])

\begin{tabular}{|c|c|c|c|c|c|c|c|c|c|}
\hline \multicolumn{1}{|c|}{ МВ } \\
\hline & $\mathrm{Cu}$ & $\mathrm{Cu}+\mathrm{As}$ & $\mathrm{Cu}+\mathrm{Sn}$ & $\mathrm{Cu}$ & $\mathrm{Cu}+\mathrm{As}$ & $\mathrm{Cu}+\mathrm{Sn}$ & $\mathrm{Cu}$ & $\mathrm{Cu}+\mathrm{As}$ & $\mathrm{Cu}+\mathrm{Sn}$ \\
\hline Анатолия & 62 & 31 & 2 & 15 & 74 & 8 & 13 & 51 & 32 \\
\hline Месопотамия & 100 & 0 & 0 & 14 & 74 & 8 & 16 & 38 & 45 \\
\hline Левант & 0 & 0 & 0 & 39 & 57 & 1 & 20 & 38 & 39 \\
\hline Иран & 44 & 53 & 0 & 29 & 70 & 1 & 1 & 69 & 28 \\
\hline
\end{tabular}

Как прекрасно показано Дж. Мьюли, именно металлы были стержнем месопотамской торговли. С начала РД периода основные торговые пути проходили по суше, пересекая горные перевалы Тавра и Загроса. Только в РД ІІІ появился морской путь поставок металла через Персидский Залив и далее через Сиппар по Евфрату в Мари, в результате чего стоимость меди в Шумере была значительно ниже, чем в Вавилоне и Ассирии [Muhly, 1973. Р. 208, 296, 301, 321, 323]. Лучше всего эта торговля изучена для Староассирийского периода. В начале II тыс. до н.э. за 30 лет только в Анатолию через Ассирию было перевезено около 130 тонн олова. Из этого количества можно было выплавить около 1300 тонн бронзы. Это минимальное число, полученное на основе лишь прочитанных документов, которые отражают, к тому же, только реально проданный металл [Barjamovic, 2011. Р. 11, 12]. Но часть металла оставлялась по дороге в виде дорожных сборов, которые различались и зависели от договоренностей царей Ашшура с местными правителями. Например, один прави- тель на Евфрате брал 12 шекелей (ок. 100г) олова с осла, шедшего в Каниш, и 1,25 шекеля (10г) серебра с осла, шедшего в Ашшур. Суммарно дорожные сборы составляли 5 мин (2,5 кг) на талант (30 кг) перевезенного груза, а загрузка одного осла составляла 75 кг. Но и в Канише правители брали 2/65 олова [Dercksen, 2005. Р. 17, 19, 20]. Были также платы за пересечения бродов и мостов, за услуги караван-сараев [Barjamovic, 2011. Р.22-26, 35]. Соответственно, минимальным годовым объемом перевозок только через Каниш было 52,5 тонны олова. А была еще масштабная торговля Месопотамии с Ираном и торговля иными товарами. Олово было стратегическим товаром, направленным на поддержание отношений с анатолийскими правителями, оно давало минимальную прибыль в торговых обменах, где в основе лежали поставки тканей и иных товаров из Месопотамии в обмен на анатолийское серебро. Кроме того, ассирийские купцы осуществляли перевозки меди и шерсти внутри Анатолии [Barjamovic, 2011. Р.12-14].

${ }^{4}$ Существуют и иные периодизации, в данном случае нам важно лишь соотношение роста металлопотребления с хронологией. 
Хорошо известные в Месопотамии тяжелые повозки, запряженные быками, для этих целей использовать было нельзя из-за состояния дорог. К востоку от Евфрата анатолийские источники не содержат упоминаний о повозках. Поэтому все перевозки осуществлялись с помощью вьючных животных. Общая протяженность путей ассирийских торговцев простиралась на тысячи километров, и поездка в один конец занимала 5-6 недель, при этом животным требовался отдых. Обычно осел под вьюком преодолевал в день 30-35 км. Кроме того, при обратных перевозках серебра в Месопотамию требовалось намного меньше ослов, и излишки продавались в Канише. В одном документе упоминается караван, состоявший из 300 ослов [Barjamovic, 2011. P. 15-18, 19, 20, 35]. Соответственно, должны были существовать хозяйства, в которых выращивали этих животных. Эта торговля являлась делом частных компаний и была высоко конкурентной. Поэтому торговцы стремились снижать издержки, а транспортные расходы были крайне высоки. Стоимость зерна в Иране удваивалась по сравнению с ценой производителя [Edens, Kohl, 1993. Р. 30], то же происходило и с оловом после доставки его из Ашшура в Анатолию [Muhly, 1973. P. 207].

Оптимальным животным для этой работы был мул. Его преимущества по сравнению с ослом - гораздо большая выносливость и способность перевозить намного большие грузы и под вьюком, и в запряжке. Кроме того, мула отличает более спокойный и покорный нрав, более простой уход, гораздо лучшее здоровье и большая продолжительность жизни. Эти рабочие качества сказывались на цене. В III тыс. до н.э. осел стоил 4-5 шекелей серебра, а мул пол мины, то есть в 6 раз дороже [Zarins, 1978. Р.14], что было важным стимулом для его разведения. Мулы являются результатом скрещивания осла с кобылой. Есть другой вид гибрида, лошак, получаемый скрещиванием жеребца с ослицей. Но его выведение менее результативно, и этот гибрид не всегда удачен. Причина этого чисто биологическая: осел имеет 62 хромосомы, а лошадь 64. Скрещивание является более удачным, если количество хромосом у самца меньше. Но для производства мулов необходимо держать в неволе табун кобылиц. Соответственно, мы должны обратиться к фактам присутствия лошади в регионе.

\section{Остеологические данные}

\section{о лошади на Ближнем Востоке}

Принято считать, что Ближний Восток не входил в ареал распространения диких лошадей, лошадь появилась там после 2500 г. до н.э. и не играла никакой роли [Кузьмина, 2000. С. 11, 13, 14; Епимахов, Чечушков, 2018. С. 156]. Тем не менее, ранние свидетельства ее присутствия многочисленны (рис. 1).

На поселениях Арухло I и Цопи шулавери-шомутепинской культуры Закавказья кости лошади обнаружены в слоях VI-V тыс. дон.э. (кал.). На позднеэнеолитическом поселении Аликемектепеси (IV тыс. дон.э., кал.) кости лошади составляют 7,5\% остеологического материала, причем принадлежат они двум породам [Энеолит СССР, 1982.

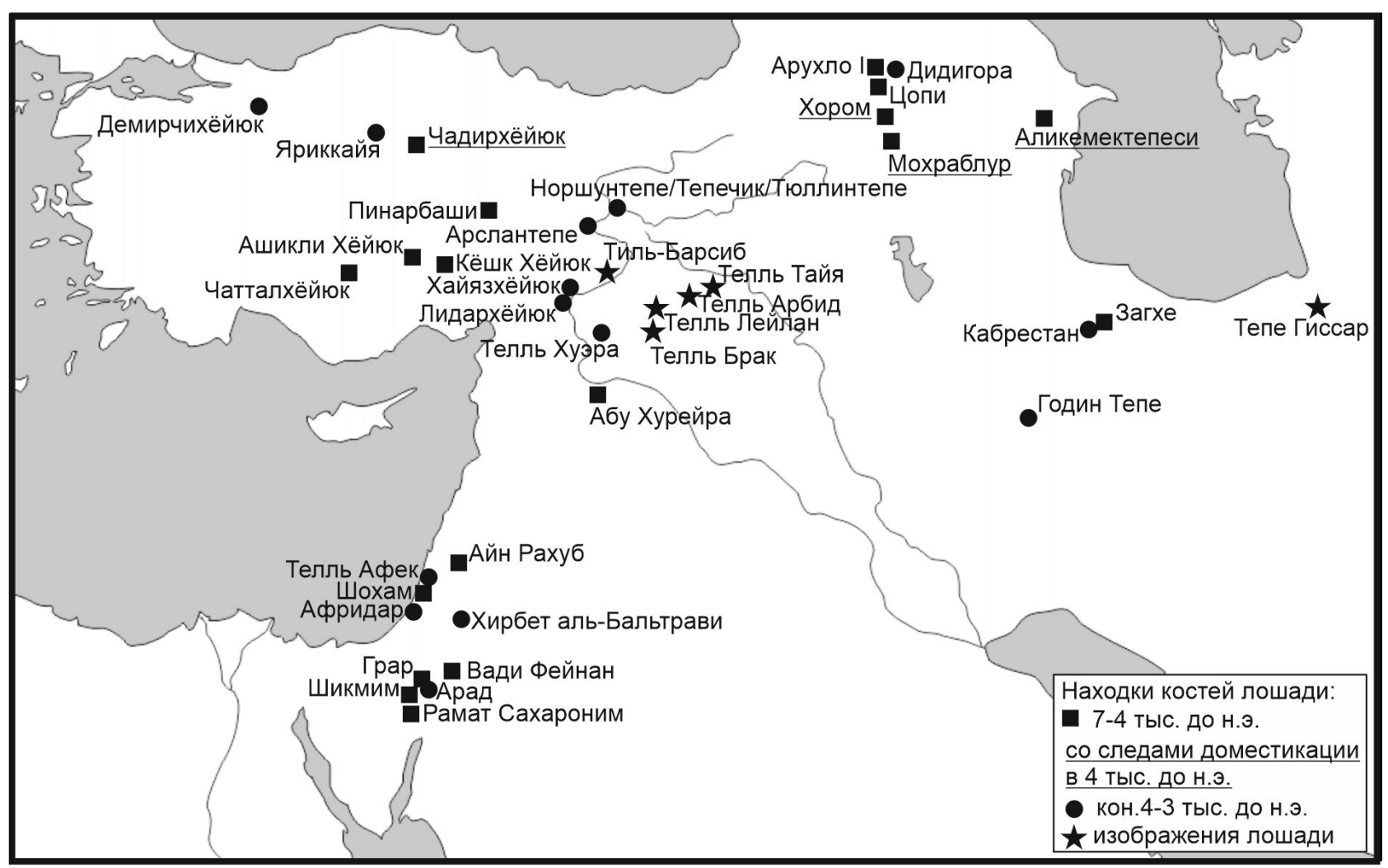

Рис. 1. Ранние находки костей лошади и изображений на Ближнем Востоке (по: [Grigson, 2012; Shev, 2016; Guimaraes et al., 2020])

Fig. 1. Early finds of horse bones and images in the Near East (after [Grigson 2012; Shev 2016; Guimaraes et al. 2020]) 
C. 134, 135]. На поселении Хором (3371-3136гг. дон.э., кал.) кости лошади составляли 6,7\% остеологического материала [Shev, 2016. Р. 128]. Впоследствии лошадь известна в куро-аракской культуре РБВ Закавказья. С.Пиготт полагал, что это была дикая лошадь, но основанием для этого вывода было то, что в Южной Месопотамии безусловное свидетельство использования лошадей появляется только в конце IIIтыс. дон.э. (кал.) [Piggott, 1992. P. 48]. Данные из Южной Месопотамии не могут быть основанием для выводов по Закавказью, но ввиду быстрой изменчивости лошадей, присутствие двух пород на Аликемектепеси можно объяснить охотой на популяции, проживающие в разных местах обитания. Дополнительным свидетельством возможной доместикации может быть выявление следов использования удил на лошадином зубе из позднеэнеолитического слоя в Мохраблур в Армении [Anthony et al., 2006. P. 148; Anthony, 2007. P. 221]. В качестве еще одного аргумента приводится отсутствие в Закавказье лошади в слоях раннего голоцена, поэтому предполагается, что лошади были импортированы из Понто-Каспийской степи, и вскоре они проникли южнее, хотя там известны и дикие лошади [Shev, 2016. Р. 127, 128]. Но шулавери-шомутепинская культура предшествует гипотетическому степному коневодству. Кроме того, мы можем допускать миграцию диких табунов, как из степи, так и из Анатолии.

В Анатолии дикая лошадь сохраняется после плейстоцена. В центре и на востоке ее кости обнаружены в неолитических слоях Чаталхююк и Пинарбаши (7400-6200 гг. до н.э. (кал.), а на поселении Кёшк Хююк в VIтыс. дон.э. конина была основной пищей, как и на Ботае, что указывает, скорее, на дикую лошадь. По всему региону кости лошади присутствуют в слоях IV-IIIтыс. дон.э. (кал.), и уже в позднем энеолите на поселении Чадир Хююк (вторая половина IV тыс. дон.э., кал.) появляются первые признаки доместикации: $20 \%$ костей стопы имеет патологию, позволяющую предполагать использование лошадей в качестве вьючных животных и говорить об Анатолии, как о втором ареале доместикации [Shev, 2016. Р. 129]. Но неолитическая лошадь Анатолии не является предком современной домашней лошади [Librado et al., 2021]. Существует общее мнение apхеозоологов, что домашние лошади в Анатолии определенно присутствуют в IIIтыс. до н.э. (кал.) (Демирчиуйюк, Яриккая, Хаяз Хююк), а лошади конца IV - начала IIIтыс. дон.э. (кал.) (Тепечик, Тюлинтепе, Норшун Тепе) могут быть реликтами диких плейстоценовых лошадей [Grigson, 2012. P. 186]. Поэтому в Анатолии мы можем допускать начало доместикации во второй половине IV тыс. до н.э. (кал.), но определенно о домашних лошадях можно говорить лишь с IIIтыс. до н.э. (кал.).

В Сирии на поселениях IV тыс. до н.э. выявлены кости двух видов эквидов: осла и онагра. Ев- ропейский осел жил в Леванте в плейстоцене, а в неолите в Анатолии и Иране, но в Сирии и Леванте в доисторическое время его нет, и он здесь появляется в уже одомашненном виде. ${ }^{5}$ Лошадь в Сирии была известна в плейстоцене, но потом исчезла. Только на севере Сирии в Абу Хурейре найдены кости лошади VII тыс. до н.э. (кал.) [Grigson, 2012. Р. 186]. Устойчиво ее кости встречаются в слоях с середины III тыс. до н.э. (кал.), что позволяет рассматривать этих лошадей в качестве домашних. Самое раннее их появление в слое Телль Хуэры датировалось 2650г. дон.э. (кал.) [Vila, 2006. Р. 101, $102,115-118]$, но потом эти кости были отнесены тем же автором ко IIтыс. дон.э. [цит. по: Grigson, 2012. P. 186]. Поэтому более надежной датой появления домашней лошади является середина III тыс. дон.э.

В Южном Леванте, в Негеве, кости лошади обнаружены на нескольких позднеэнеолитических поселениях (Грар, Гилат, Шикмим) IV тыс. дон.э. (кал.), и поскольку до этого в регионе не было дикой лошади, они рассматриваются как домашние [Grigson, 2012. Р.186]. Эти находки редки в РБВ и СБВ, но потом, в ПБВ, когда в регионе надежно документированы колесницы, они исчезают с поселений. Это объясняется специфическими коневодческими практиками и тем, что лошадей не употребляли в пищу [Shev, 2016. P. 132-134]. В регионе известны отдельные фигурки лошади времени РБВ I (начало этого период относится к 3900/3800 г. дон.э. (кал.). Некоторые из находок можно трактовать как кости не лошади, а мула, но наличие мулов тоже указывает на присутствие лошадей. Кроме того, в одном случае обнаружены следы от удил на втором премоляре. Тем самым, в Южном Леванте лошадь присутствует уже в энеолите, а первые признаки домашней лошади появляются так же рано, как в Анатолии, но они не слишком надежны и недостаточны для суждений о доместикации. Эта ситуация может иметь разные объяснения: ранним заимствованием коневодства из Анатолии или миграцией оттуда диких табунов. Более вероятен второй вариант, так как если лошадь действительно использовалась в Анатолии в качестве вьючного животного, в Сирии и Леванте эту функцию выполняли более подходящие для этого ослы. С середины III тыс. дон.э. (кал.) появляются эпиграфические данные из Эблы и Телль Бейдара о скрещивании ослов с онаграми, а в Телль Браке найдены кости этого гибрида (около 2200 г. дон.э. (кал.). Присутствие мулов указывает также на скрещивание ослов с лошадьми, что не говорит о доместикации последних [Vila, 2006. P. 116; Grigson, 2012. Р. 188, 189, 191-195]. Это совершенно справедливо, поскольку наличие гибридов осла и онагра тоже не указывает на доместикацию онагра.

На северо-западе Ирана, на равнине Казвин, в энеолитических поселениях выявлены кости онагpa, небольшое количество костей осла и лошади,

${ }_{5}^{5}$ Осел был доместицирован в Египте, откуда и попал в Левант [Beja-Pereira et al., 2004; Grigson, 2012. Р. 188]. 
отсутствовавшей здесь после перехода к голоцену. Самое раннее появление дикой лошади на поселении Загхэ относится к позднему неолиту (конец VI - Vтыс. дон.э., кал.). Позднее кости лошади появляются в энеолитических поселениях, а затем в слое IV на Годин Тепе (около 3000 г. дон.э., кал.), который относится к культуре Яник, варианту куро-аракса [Mashkour, 2004. Р. 133-136]. Надежные данные об одомашнивании в этот период отсутствуют. В Восточном Иране в IV-IIIтыс. дон.э. (кал.) кости лошади не обнаружены [Shev, 2016. P. 127]. На юге Средней Азии они отсутствуют в слоях Намазга V, но появляются в слоях Намазга VI, что соответствует Бактрийско-Маргианскому археологическому комплексу [Щетенко, 2008. C. 220, 221, 225].

Таким образом, плейстоценовая лошадь сохраняется только в Анатолии и Северной Сирии. В Закавказье, Леванте и северо-западном Иране лошадь появляется в VI-V тыс. дон.э. (кал.), но данных об ее одомашнивании нет, скорее всего, это результат миграции диких табунов. Во второй половине IV тыс. дон.э. (кал.) были попытки приручения лошади в Анатолии для перевозок грузов, но это не могло закончиться успехом, так как без подков копыта лошади при таком использовании быстро изнашиваются. Ослы для этого приспособлены лучше. В Леванте в это же время начинается скрещивание лошадей с ослами и производство мулов, и это получает дальнейшее развитие на Ближнем Востоке. Здесь же, а также в Закавказье, появляются единичные данные об использовании лошадей в упряжке, но это получает развитие лишь во второй половине IIIтыс. до н.э. (кал.), когда лошади более широко распространяются на Ближнем Востоке. В Восточном Иране остеологические данные о лошадях есть только с начала ІІ тыс. до н.э. (кал.).

\section{Иконография}

Присутствие лошадей подкрепляется многочисленными изображениями. Этот источник важен тем, что позволяет выяснить возможные области их применения. Поскольку в IIIтыс. до н.э. на Ближнем Востоке известны ослы, лошади, онагры и гибриды этих видов, сделать точные различения по небольшим фигуркам сложно. Некоторые способы идентификации возможны по форме грив и хвостов (см. вертикально торчащие гривы эквидов, как у ослов, на рис. 2, 1 и лежащие на шее, как у лошадей, на рис. 2, 2-4). В некоторых случаях признаком лошади являются маленькие уши на коротких головах с выпуклыми лбами, длинными шеями и высоко обрезанными хвостами. Поэтому некоторые изображения в Тилль Барсибе в Сирии и из Карума Каниша II и Ib могут фиксировать присутствие лошадей [Littauer, Crouwel, 1979. P. 26, 57].

На поселении Телль Арбид в бассейне Хабура обнаружено около 650 статуэток, из которых 44\% относятся к эквидам, и аналогичные находки сделаны на иных поселениях региона (Телль Мозан, Телль Брак, Телль Лейлан, Телль Тайя) РД ІІІ и Ак- кадского периодов (рис. 2, 4). Такая значительная база данных позволила выделить признаки (орнаментальные линии или полосы), которые изображают детали упряжи и те, которые отражают вид животного. Отличительным признаком лошади и онагра являются полосы по хребту при отсутствии полос по плечам, характерных для изображений ослов. Изображения этого типа появляются во второй половине IIIтыс. до н.э., когда на Ближнем Востоке известна лошадь в текстах и иконографии и сокращается значение онагра, которого держали для скрещивания. Дополнительным аргументом является то, что на этих изображениях встречаются отверстия в морде для удил, а онагров никогда не взнуздывали и не запрягали. Некоторые фигурки дополнены изображениями чепраков, а во всех более поздних и отчетливых изображениях Ближнего Востока чепрак присутствует исключительно на изображениях лошадей [Makowski, 2014].

Самым ранним изображением эквидов в упряжке является штандарт из Ура (рис. 2, 1), датируемый около 2600 г. дон.э. [Littauer, Crouwel, 1980. Р. 344]. В тяжелую четырехколесную повозку запряжено четыре эквида, контроль за которыми осуществляется с помощью носовых колец. Это явно не лошадь, а гибрид осла с онагром или лошадью. В модели повозки из Телль Аграб в Сирии запряжены, по-видимому, четыре осла [Littauer, Crouwel, 1979. Fig. 7]. Более поздние изображения запряжек в четырех- и двухколесные повозки с колесами с ободом и двумя перекрещивающимися планками, с аналогичным способом контроля, присутствуют на цилиндрических печатях из слоя Карум Каниш II с датой 2000-1850 гг. дон.э., и здесь лошади уже не исключены (рис. 2, 2). Явные лошади появляются на изображениях на сирийских печатях с середины XIX в. до н.э., где они запряжены в колесницы со спицами (рис. 2, 3) [Moorey, 1986. P. 198, 201, 202. Pls. 2, 5]. Эта эволюция в использовании эквидов тесно связана с эволюцией транспортных средств от тяжелых повозок к двуколкам и затем к легким двуколкам со спицами. Двуколки не были видом транспорта, необходимым в хозяйственных целях. Анализ изображений и письменных источников показывает ограниченные области их применения: в военных целях, поездках, на охоте, для парадных выездов и процессий, в качестве транспорта богов [см. W. Färber в Littauer, Crouwel, 1980. Р. 336]. Соответственно, появление этого вида транспорта было возможно лишь в обществах, где выделилась элита, которая могла себе позволить содержание подобных экипажей, и это вполне соответствует ситуации на Ближнем Востоке в этот период.

Даты в Восточном Иране более ранние. В первую очередь, это печать из Тепе Гиссар IIIB, на которой изображена колесница со спицами, запряженная крупным эквидом (рис. 2, 5) [Teufer, 2012. Р. 292, 295]. Это изображение давно известно и обычно в российской археологии не рассматривается, поскольку считается, что там изображен иной эквид, осел или онагр. Но онагры никогда 

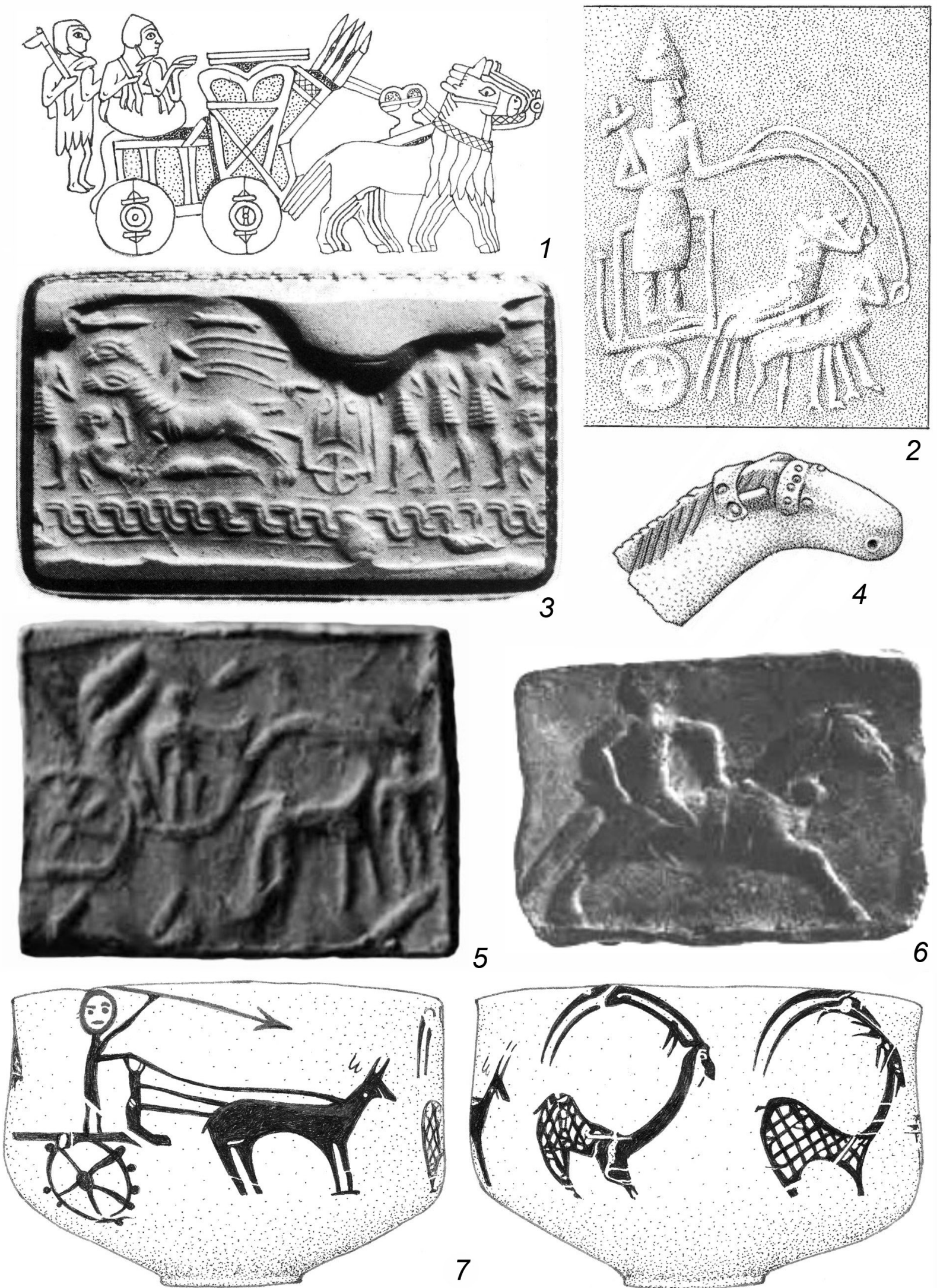

Рис. 2. Изображения эквидов: 1 - штандарт из Ура, фрагмент (2600 г. до н.э.); 2 - оттиск печати из Канеш II (1970-1840 гг. дон.э.); 3 - оттиск печати из Сирии (1750-1600 гг. до н.э.), музей Эшмола; 4 - Телль Тайя; 5 - оттиск печати, Гиссар IIIB; 6 - глиняная пластина из Ирака; 7 - сосуд из Восточного Ирана (1, 2 - [Littauer, Crouwel, 1979]; 3 - [Moorey, 1986]; 4 - [Littauer, Crouwel, 2001]; 5, 7 - [Teufer, 2012]; 6- [Moorey, 1970])

Fig. 2. Equidae image: 1 - Standard of Ur, fragment (2600 BC); 2 - seal imprint from Kanesh II (1970-1840 BC); 3 - seal imprint from Syria (1750-1600 BC), Ashmolean Museum; 4 - Tell Taya; 5 - seal imprint, Hissar IIIB; 6 - clay plate from Iraq; 7 - vessel from Eastern Iran (1, 2 - [Littauer, Crouwel 1979]; 3 - [Moorey 1986]; 4 - [Littauer, Crouwel 2001]; 5, 7 - [Teufer 2012]; 6 - [Moorey 1970]) 
не были одомашнены, а для осла это животное слишком крупное. На то, что это лошадь, указывает сосуд с антикварного рынка в Восточном Иране. На нем изображена сцена охоты на газелей копьем на колеснице со спицами, запряженной эквидом (рис.2,7). Этот сосуд сопоставим с посудой из Тепе Яхья периодов IVB5 и IVB4 (конец III тыс. до н.э.). Аналоги этой керамике встречаются в Восточном Иране в ареале между Тепе Яхья и Шахдадом во второй половине III тыс. до н.э. (кал.) [Teufer, 2012. Р.296, 299]. Отождествление этого животного с лошадью возможно по той причине, что охота с копьем на газелей на колеснице, запряженной ослом, невозможна. Современные AMS даты Гиссара III не выходят за пределы XVIIIв. дон.э. (кал.), причем поздняя часть этого интервала представлена слоем Гиссар IIIC [Gürsan-Salzmann, 2016]. Соответственно, слой IIIB относится к III тыс. дон.э. (кал.). При всей дискуссионности вопроса датировки периода IVB на Тепе Яхья, он может начинаться около 2800 г. до н.э. (кал.), хотя более вероятны радиоуглеродные даты в пределах второй половины IIIтыс. до н.э. (кал.), и очень сомнительно, что этот период заходит во IIтыс. до н.э. (кал.). Частично он синхронен РД периоду Месопотамии, но, главным образом, Аккадскому (2334-2154 гг. до н.э.), и возможно, отчасти постАккадскому [Potts, 2001. P. 196, 203, 215, 221; Lamberg-Karlovsky, 2001. P.271, 274, 276]. В любом случае, это заметно предшествует синташтинской культуре с самыми ранним степными лошадьми, и печатям из Каниша. Эти изображения вступают в противоречие с фактом отсутствия костей лошади на поселениях региона вплоть до начала II тыс. до н.э., что можно объяснить исключительным использованием лошади для упряжки в престижные повозки. Но это исключает данный регион из ареалов возможной доместикации.

Верховая езда документируется редкими данными. Это серия изображений всадников на обожженных глиняных табличках периодов РДІІІ, Исин-Ларса и Старовавилонского. Обычно животных на этих изображениях идентифицируют как онагров (С.Г. - не существует данных о доместикации онагра, поэтому часть этих изображений может быть гибридами), но есть надежные изображения лошадей (рис. 2, 6). Наиболее раннее относится, вероятно, к периоду РД ІІІ. Посадка всадника очень неуверенная, он смещен к крупу лошади, как при посадке на осла. Во всех случаях, где это различимо, контроль за животным осуществляется с помощью носового кольца [Moorey, 1970. Р. 36-49]. Сторонники степного происхождения колесничества пытаются объяснить эти факты импортом лошадей из синташтинской культуры в Южную Месопотамию периода III Династии Ура через Иран [Anthony et al., 2006. Р. 147]. Это сомнительная возможность и ее можно полностью исключить по хронологическим причинам, так как этот период (не говоря уже о периоде РД III) значительно предшествует Синташте в Зауралье.
Таким образом, мы видим парадоксальную картину. В литературе по этой проблеме существует убеждение, что использование лошадей в парных запряжках предшествует их использованию для верховой езды. Отчасти это связано с психологией животного [Bökönyi, 1993], но безусловна и более поздняя хронология всадничества. Однако на Ближнем Востоке изображения лошади с уздой появляются во второй половине IIIтыс. дон.э., что вполне соответствует данным об использовании узды для прочих эквидов. К середине этого тысячелетия относится и первое изображение всадника. Единичные подобные изображения встречаются и позже. Но это либо не было широко распространено, либо использовалось в тех сфеpax, которые не отражают источники этого типа. Использования лошади в упряжке этого времени мы не знаем. В повозки запрягают каких-то гибридов, возможно, ослов и мулов. Надежные свидетельства использования лошадей прочно связаны с появлением легкой повозки со спицами в начале II тыс. до н.э. в Сирии, и в последней трети III тыс. до н.э. - в Восточном Иране. Этот парадокс проясняется при обращении к письменным источникам.

\section{Письменные данные}

В месопотамских письменных источниках термин для лошади появляется в IIIтыс. дон.э. Первичная логограмма ANŠE использовалась для эквидов в целом, но специфически для осла, а с конца IIIтыс. дон.э. исключительно для осла, который известен в Месопотамии с РД периода. Термин для лошади на протяжении месопотамской истории менялся: в шумерских и староаккадских источниках он присутствует в виде логограмм ANŠE.ŠUL.GI и ANŠE.ZI.ZI. Первый вариант появился в РДI/II и исчезает в конце РДIIIb, когда его заменила логограмма ANŠE.LIBIR в староаккадском и старовавилонском языках, а с периода Исин-Ларса - ANŠE.KUR.RA. Логограмма ANŠE. ZI.ZI относится к периоду III Династии Ура [Zarins, 1978. P.4, 5, 7-10; Littauer, Crouwel, 1979. P. 26, $27,42,43,58]$. Это указывает на знакомство месопотамского населения с лошадью в III тыс. до н.э., хотя Месопотамия не была ареалом обитания диких лошадей.

В этом контексте для нас важно понять, как лошадь была одомашнена на Ближнем Востоке. Поскольку первый термин ANŠE.ZI.ZI означал «быстрый осел», а второй ANŠE.KUR.RA - «осел с гор», Р.Дрюс считал, что лошади в Месопотамию импортировались из районов к югу от Кавказа. При этом, поскольку сведения этого времени о всадничестве ограничены, а устойчивое использование лошади начинается лишь с появлением колесниц, он полагал, что лошадей в это время везде разводили для мяса [Drews, 2017. Р.33, 37, 40-42, 49]. Но это сомнительно даже для ареалов обитания лошади, а импорт лошадей с этой целью в Южную Месопотамию и вовсе нереален.

Обсуждая проблемы и условия доместикации лошади и социально-экономические условия Ближнего Востока, мы видели, что для устойчивой 
доместикации были нужны специфические условия, которые сложились в этом регионе. Важным фактором в проблеме одомашнивания лошадей было присутствие других эквидов: дикого онагра и домашнего осла, который широко использовался как вьючное животное. При этом онагр никогда не был одомашнен [Zarins, 1978. P. 17], но с середины IIIтыс. до н.э. началась практика его скрещивания с ослом, в результате чего появились более эффективные, но бесплодные гибриды. Эта практика подразумевает содержание в неволе диких онагров и диких или домашних лошадей, что открывало широкие возможности для племенной работы. Более подробную информацию об этом процессе мы можем получить из письменных источников, и эта проблема подробно изучена Дж.Заринс [Zarins, 1978. P.9, 11, 13-15, 17; Zarins, Hauser, 2014. P. 171174]. В документах РД и Староаккадского периодов упоминаются мулы (ANSE.BAR.AN), что о3начает практику скрещивания ослов с лошадьми. В зависимости от типа скрещивания существует два возможных бесплодных вида: лошак (потомство ослицы и жеребца) и мул (потомство осла и кобылы). В документах чаще всего фигурируют мулы, а лошаки (KŪDANU, GIR.NUN) встречаются редко, так как их сложнее производить и содержать. Один документ Староаккадского периода описывает 6 человек, связанных с 200 эквидами (т.е. относительно крупное хозяйство), и среди этих эквидов есть взрослые кобылы (ANŠE.LIBIR.SAL. GAL), дававшие потомство в виде мулов (ANŠE. BAR.AN) и жеребят (ANŠE.LIBIR). По текстам РД периода от кобыл ANŠE.ŠUL.GI родились жеребята ŠUL.GI и мулы BAR.AN. Существовал еще один редкий тип гибрида, NISKUM, что могло о3начать онагра или гибрид осла и онагра. Но смысл этого термина не ясен. Онагров иногда включали в табун, но никогда не приручали. Возможно, практика скрещивания ослов и диких онагров кое-где продолжалась, но к концу III тыс. до н.э. она исчезла полностью [Lafont, 2000. P. 211].

Эти документы дают нам четкую информацию о процессе приручения лошади. Для получения мулов, оптимальных как вьючное животное, так и для запряжки в повозки, было необходимо содержать кобыл, взятых из табунов диких лошадей. Однако продолжительность жизни лошадей 25-30 лет, а репродуктивный период еще короче. Следовательно, это стадо приходилось обновлять. Но поймать диких кобыл и перевезти их за сотни километров было сложно и дорого. Гораздо проще содержать в табуне одного или двух жеребцов, что объясняет эти два типа потомства кобыл, которые упоминаются в документах. Таким образом, возникла ситуация установленного генетиками значительного матрилинейного и низкого патрилинейного разнообразия лошади [Lindgren et al., 2004]. Содержание большого количества жеребцов при подобном использовании было экономически невыгодным. При этом проводилась селекция лошадей, так как селекция мулов невозможна. Следовательно, на Ближнем Востоке сформировалось два необходимых условия для приручения лошади: 1)длительное содержание дикой лошади в неволе для скрещивания; 2) четкое понимание, с какой целью и в каком направлении нужно проводить контролируемую селекцию. В специфических условиях Ближнего Востока это было не только экономически оправдано, но и чрезвычайно выгодно с первого года, поскольку целевой продукцией были мулы, стоившие гораздо дороже ослов.

В этих условиях было возможно приручить лошадей, поэтому мы видим не только их упоминания, но и изображения со всадником. В результате лошадь время от времени появляется в источниках, но ее роль была вспомогательной в производстве мулов. Использовать лошадь в качестве вьючного животного было экономически нецелесообразно: мул мощнее лошади при сравнении их веса, продолжительность его жизни намного дольше, подверженность заболеваниям меньше, уход проще и дешевле, трудоспособный возраст начинается раньше (в 4 года по сравнению с 5-7 годами лошади), наконец, мул намного выносливее. Все эти преимущества резко возрастают в горной местности, а торговые пути через Загрос и Тавр были основными в торговле. Логограмма ANŠE. ŠUL.GI, которая использовалась в периоды РД и III Династии Ура для обозначения лошадей, встречается в ассоциации с ярмом [Zarins, 1978. P.6], что указывает на эпизодическое использование лошадей в упряжке. Но до появления легких повозок такая практика не могла получить широкого распространения. Этим объясняется скромное присутствие лошади в источниках, большинство из которых представлено документами торговцев, которые лошадь не использовали [Michel, 2004. P. 195].

Существование практики верховой езды не ясно, данных об использовании лошадей на войне нет, вероятно, они служили для поездок курьеров. Ослы и гибриды использовались для верховой езды, и вероятно, езда на лошади восходит к этой традиции, так как даже в начале IIтыс. до н.э. в упряжи верховых лошадей применялись носовые кольца [Littauer, Crouwel, 1979. Р. 45, 46, 59, $70,72]$. Есть смутные упоминания о всадничестве в Сирийской пустыне в начале II тыс. до н.э., но не слишком надежные [Moorey, 1986. Р. 198]. Есть данные о переписке руководителей караванов с торговцами, что предполагает наличие каких-то гораздо более быстрых средств коммуникации, чем 30-35 км в день, проходимые караваном, и некоторые источники позволяют предполагать наличие как бегунов, так и конных посыльных [Barjamovic, 2011. Р. 17, 18]. Но в престижном контексте, военном деле и хозяйстве верховая езда отсутствовала, что объясняет ее скромное отражение источниками. Известно письмо Бахди-Лима царю Зимри-Лиму в Мари, в котором он советует ехать не на лошади, а на муле или в колеснице, как положено царю [Moorey, 1986. Р. 48]. Вероятно, этот царский протокол был первоначально обусловлен соображениями безопасности, так как до появле- 
ния кавалерии и соответствующей упряжи контролировать поведение лошади было сложно.

Сирийские тексты из Чагар Базара XVIIIв. дон.э. упоминают упряжки лошадей, конюхов и тренеров. Но они не описывают отчетливо функцию лошадей. По информации из Мари того же времени, лошади были ценными животными и их тренинг был связан с царской семьей, что указывает на использование лошадей в престижной упряжке, в колесницах. Один текст сообщает, что лошади поступали в Мари и царю Ассирии с запада, из внутренней Сирии и Анатолии [Moorey, 1986. Р. 198]. Но в этом случае речь идет о более позднем периоде, когда колесничество распространилось на Ближнем Востоке.

\section{Упряжь}

Данные о совместной эволюции колесного транспорта и различных типов эквидов хорошо подкрепляются соответствующей эволюцией упряжи. Прототипом упряжи эквидов была упряжь, используемая в бычьих повозках, где ярмо крепилось к рогам. Поскольку анатомия эквидов этого не позволяет, уже в середине III тыс. до н.э. ярмо смещается в район плеч животных, где и крепится к дышлу, а также появляются широкие хомуты, как это показано на модели из Телль Аграба и на штандарте из Ура. Затем происходит отказ от крепления повода к носовому кольцу, появляется оголовье и узда, к которым и крепится повод, а ярмо было заменено седёлкой. Эта плавная эволюция на Ближнем Востоке хорошо отражена в изображениях и детально описана [Littauer, Crouwel, 1979. P. 14, 28-31, 61, 72; 2001. P. 335; Makowski, 2014. Р. 262, 264, 267]. Вероятно, некоторое время разные типы узды сосуществовали. Во всяком случае, несмотря на схематичность изображения, создается впечатление, что на печати из Карума Каниша II эквиды запряжены с помощью носового кольца. В аккадском языке узда обозначалась двумя словами: appatu (нос) и ašâtu (челюсть) [Brownrigg, Dietz, 2004. P. 483; Brownrigg, 2006. Р. 170]. Возможно, это было вызвано определенной функцией упряжки, поскольку кольцо в носу предполагает управление человеком, идущим рядом с повозкой, а удила - управление из повозки.

Существуют и археологические свидетельства использования удил. На поселении Телль эс-Сафи в Израиле в слое времени РБ ІІІ с датой 2800-2600 гг. до н.э. (кал.) найдены вторые премоляры осла или его гибрида с онагром со следами от органических удил [Greenfield et al., 2018. Р. 1, 2, $4,12]$. Первые металлические удила для запряжки ослов выявлены на поселении Телль Брак в Сирии с датой около 2200 г. до н.э. В юго-западном Иране и Нубии в тот же период известна медная патина на зубах ослов. Но на фигурках, похожих на морду лошади, 2300-2100 гг. дон.э., из Тэлль эс-Свейхат в Сирии и Староаккадского периода из Тэлль Тайя в Ираке есть отверстия на морде в месте размещения удил [Littauer, Crouwel, 2001. Р.329, 331, 332]. Таким образом, в Леванте в первой половине III тыс. дон.э. начинают использовать органиче- ские удила для управления эквидами. Около середины III тыс. до н.э. в Сирии известны уже полные оголовья с органическими удилами, а около 2200 г. дон.э. появляются металлические, и, возможно, начинается применение этого типа узды в конской упряжи. Несколько более поздним временем датируется появление узды в Иране, где на поселении Малян на зубах лошадей обнаружены следы от удил [Anthony et al., 2006. Р. 148]. Кости лошадей на этом поселении обнаружены в слое 20001800 гг. до н.э. (кал.) [Vila, 2006. Р. 120].

\section{Дискуссия}

Обобщение разных групп источников Ближнего Востока дает достаточно согласованную и логичную картину доместикации лошади. Принципиальную возможность для этого предоставило сохранение популяции плейстоценовой лошади в Анатолии. Вероятно, ее распространение в период VII-V тыс. дон.э. (кал.) объясняет присутствие костей лошади в Закавказье, Северо-Западном Иране и Леванте. Однако для этого времени следы доместикации отсутствуют. Первые признаки этого появляются в разных регионах Ближнего Востока в IV тыс. до н.э. (кал.) и они превышают количественно и качественно признаки доместикации лошади в степной Евразии. Тем не менее, некоторые из этих признаков (стертости на зубах, наличие двух пород лошади на одном поселении, присутствие костей в ареале, где дикой лошади до этого не было) могут быть по-разному интерпретированы. Единственным заслуживающим внимания (но не доверия) фактом является патология костей стопы значительного количества лошадей на поселении Чадир Хююк в Анатолии, что допускает возможность использования лошади как вьючного животного. Однако механизм приручения, как и его мотивы, в этом случае не вполне ясны, поскольку было необходимо несколько поколений содержать диких лошадей в неволе и проводить селекцию, направленную на выведение вьючных животных. Это слишком затратное мероприятие и аналогов этому мы не знаем. Поэтому необходимы дополнительные данные для обоснования данной возможности. Тем не менее, даже если это произошло, неподкованная лошадь не приспособлена к этой работе, и она не могла составить конкуренцию ослу, подобное использование которого начало распространяться на Ближнем Востоке как раз в это время.

Важным побудительным мотивом для доместикации стало бурное развитие ближневосточной торговли в IIIтыс. до н.э., в которой основная масса товаров доставлялась на вьючных животных. Вторым фактором стало распространение домашнего осла, который использовался для этих целей и для запряжки в повозки. Третьим фактором было наличие элиты, которая практиковала езду в легких одноосных повозках, запряженных ослами или их гибридами. Наконец, важнейшим четвертым фактором была практика скрещивания домашнего осла с онагром и лошадью, в результате чего получались более приспособленные для 
этих целей, но бесплодные гибриды. Их стоимость была намного выше стоимости ослов, что делало разведение высокорентабельным предприятием. В силу биологических причин, для производства мулов было необходимо держать в неволе табун кобылиц и скрещивать их с ослами, а для воспроизводства лошадиного табуна было нужно содержание отдельных жеребцов. Тем самым были созданы уникальные условия для доместикации лошади и селекционной работы, причем в этом случае это был не затратный, а прибыльный процесс с самого начала.

Этот процесс отражен во всех группах источников IIIтыс. до н.э., но наиболее интенсивно с середины этого тысячелетия: в текстах, иконографии, остеологических материалах. При подобном содержании лошадей для выведения мулов, они играли вспомогательную роль в хозяйстве. При этом создавались условия для иного использования лошадей, например, для верховой езды. Но это было ограничено курьерской службой. Самостоятельное значение лошади приобретают лишь с появлением легких одноосных повозок или колесниц в начале II тыс. до н.э., и с этого времени они хорошо представлены в источниках.

Предстоит разобраться с деталями этого процесса доместикации, в частности, с конкретной сферой применения мулов по причине их дороговизны в сравнении с ослом. Наиболее очевидной является запряжка в одноосные повозки, что могла позволить себе элита. Они, безусловно, использовались и для торговых перевозок, но, вероятно, не везде. Месопотамская торговля этого периода отличалась очень сложно продуманной логистикой. Поэтому мулы не могли быть основой караванов, курсировавших, например, между Канишем и Ашшуром, так как при формировании каравана в Канише часть вьючных животных продавалась, а я думаю, что производство мулов осуществлялось, главным образом, в Анатолии. Тем самым, мы получаем логистическое противоречие. Поэтому более вероятно их использование для обеспечения торговых путей в Анатолии, а также для перевозки грузов в повозках на более короткие расстояния. Это могло быть дополнительным стимулом в доместикации именно лошади. Но детали этого вопроса еще предстоит выяснить.

\section{Выводы}

Сведения о доместикации лошади в степной Евразии крайне ограничены до появления колесниц в начале IIтыс. до н.э. Это обусловлено трудностями доместикации и содержания этого вида и отсутствием для этого существенных социальноэкономических причин. Подобная ситуация характерна для большинства ареалов обитания дикой лошади, поскольку везде могли быть отдельные эпизоды приручения ограниченного количества особей, но строгих доказательств этому нет. К тому же, до появления потребности в лошади, связанной с ее использованием для запряжки в легкие одноосные повозки, это не могло превратиться в заметный социально-экономический феномен. В противоположность этому, к IIIтыс. до н.э. на Ближнем Востоке сложилась уникальная ситуация, которая не просто создавала условия одомашнивания лошади, а делала это неизбежным. Основным мотивом для этого стал рост торговли и необходимость производства мулов в качестве вьючного и упряжного животного. Но только с появлением колесниц лошадь становится видом, имеющим самостоятельное значение в жизни человека. В итоге, наиболее ранние следы доместикации сегодня мы имеем на Ближнем Востоке. Из этого не следует, что именно ближневосточная лошадь была предком лошадей бронзового века всех иных территорий, так как с распространением этого явления в другие ареалы в домашнюю популяцию могли включать лошадей из диких местных табунов.

\section{Благодарности}

Я глубоко признателен П.А. Косинцеву за чтение этого текста, его обсуждение и помощь в понимании биологических проблем.

\section{СПИСОК ЛИТЕРАТУРЫ}

АвиловаЛ.И. Металл Ближнего Востока. Модели производства в энеолите, раннем и среднем бронзовом веке. М.: Памятники исторической мысли, 2008. 227 с.

Григорьев С.А. Хронология синташтинских и ближневосточных колесниц // Magistra Vitae. 2020. №2. C. 69-80. DOI: 10.24411/2542-0275-2020-0206

Епимахов А.В., Чечушков И.В. «Ех oriente lux»? Генезис колесницы в свете новейших данных археологии // Вестник Томского государственного университета. История. 2018. №54. С. 155-160. DOI: $10.17223 / 19988613 / 54 / 24$

Калиева С.С., Логвин В.Н. Некоторые штрихи к проблеме одомашненности лошади терсекских и ботайских памятников // Вестник археологии, антропологии и этнографии. 2011. №2(15). С.246255 .
Косиниев П.А. Происхождение «колесничных» лошадей // Происхождение и распространение колесничества / Отв. ред. А.И. Василенко. Луганск: Глобус, 2008. С. 113-129.

КотоваН.С. Дереивская культура и памятники Нижнемихайловского типа. Киев, Харьков: Майдан, 2013. 486 с.

КузьминаЕ.E. Первая волна миграции индоиранцев на юг // Вестник древней истории. 2000. №4. C. 3-20.

Наумов И.Н. $\mathrm{C}^{14}$ хронология и факторы распространения навыков доместикации лошади на территории Восточной Европы // Происхождение и распространение колесничества / Отв. ред. А.И. Василенко. Луганск: Глобус, 2008. С. 9-19.

Телегін Д.Я. Середньостогівська культура епохи меді. Киев: Наукова Думка, 1973. 187 с. 
Щетенко А.Я. Время появления домашней лошади на территории Средней Азии // Происхождение и распространение колесничества / Отв. ред. А.И. Василенко. Луганск: Глобус, 2008. С. 219-233.

Энеолит СССР / Отв. ред. тома В.М.Массон, Н.Я. Мерперт. М.: Наука, 1982. 359 с. (Археология CCCP).

Юдин А.И. Место и время доместикации лошади по данным Варфоломеевской стоянки в степном Заволжье // Происхождение и распространение колесничества / Отв. ред. А.И. Василенко. Луганск: Глобус, 2008. С. 20-29.

AnthonyD.W. The horse, the wheel and language. Princeton: University Press, 2007. $568 \mathrm{p}$.

AnthonyD.W., BrownD.R., GeorgeCh. Early horseback riding and warfare: the importance of the magpie around the neck // Horses and Humans: The Evolution of the Equine-Human Relationship / S.L.Olsen, S. Grant, A. Choyke, L. Bartosiewicz (eds.). Oxford: British Archaeological Reports, 2006. P. 137-156.

Barjamovic G.A. Historical Geography of Anatolia in the Old Assyrian Colony Period. Copenhagen: Museum Tusculanum Press, 2011. 537p.

Beja-PereiraA., EnglandPh.R., FerrandN., JordanS., BakhietA.O., Abdalla M.A. African Origins of the Domestic Donkey // Science. 2018. № 18. Vol.304, Issue 5678. P. 1781. DOI: 10.1126/science. 1096008

BeneckeN. 10 Jahre archäogenetische Forschungen zur Domestikation des Pferdes. Die Arbeiten der Jahre bis 2018 // Die e-Forschungsberichte 2018-2 des Deutschen Archäologischen Instituts. Berlin, 2018. P. 62-70.

BökönyiS. Pferdedomestikation, Haustierhaltung and Ernährung: archäozoologische Beiträge zu historisch-ethnologischen Problemen. Budapest: Archaeolingua, 1993.61 p.

Brownrigg G. Horse control and the bit // Horses and Humans: The Evolution of Equine-Human Relationships / S.L. Olsen, S. Grant, A.M. Choyke, L. Bartosiewicz (eds.). Oxford: British Archaeological Reports, 2006. P. 165-171.

Brownrigg G., Dietz U.L. Schirrung und Zäumung des Streitwagenpferdes: Funktion und Rekonstruktion // Rad und Wagen. Der Ursprung einer Innovation. Wagen im Vorderen Orient und Europa. Beiheft der Archäologische Mitteilungen aus Nordwestdeutschland 40 / M.Fansa (ed.). Mainz a.R.: von Zabern, 2004. P. 481-490.

CzebreszukJa., KośkoA., SzmytM. The Horse, Wagon and Roads // Происхождение и распространение колесничества / Отв. ред. А.И. Василенко. Луганск: Глобус, 2008. С.47-54.

DercksenJ.G. Metals according to documents from Kültepe-Kanish dating to the Old Colony Period // Anatolian Metal III. Abschnitt, Beiheft 18 / Yalcun Ü. (ed.). Bochum: Deutsches Bergbau-Museum, 2005. P. 17-34.

Drews $R$. Militarism and the Indo-Europeanizing of Europe. London: Routledge, 2017. 296 p.

Edens Ch.M., KohlPh.L. Trade and world system in Early Bronze Age Western Asia // Trade and exchange in prehistoric Europe / Ch. Scarre, F. Healy (eds.). Oxford: Oxbow Books, 1993. P. 17-34.

Fages A. et al. Tracking Five Millennia of Horse Management with Extensive Ancient Genome Time Series // Cell. 2019. № 177. P. 1419-1435. DOI: 10.1016/j.cell.2019.03.049

Gaunitz Ch. et al. Ancient genomes revisit the ancestry of domestic and Przewalski's horses // Science. 2018. № 06. Vol.360. Issue 6384. P.111-114. DOI: 10.1126/science.aoo3297

GreenfieldH.J., ShaiI., GreenfieldT.L., ArnoldE.R., BrownA., EliyahuA., Maeir A.M. Earliest evidence for equid bit wear in the ancient Near East: The "ass" from Early Bronze Age Tell eș-Șâfi/Gath, Israel // PLoS ONE. 2018. № 13(5). e0196335. https:// doi.org/10.1371/journal.pone.0196335.

Grigoriev S.A. The evolution of antler and bone cheekpieces from the Balkan-Carpathian region to Central Kazakhstan: chronology of "chariot" cultures and Mycenaean Greece // Journal of ancient history and archaeology. 2021. № 8.2. P. 148-189. DOI: $10.14795 /$ j.v8i2.633

Grigson C. Size Matters - Donkeys and Horses in the Prehistory of the Southernmost Levant // Paléorient. 2012. № 38(1-2). P. 185-201.

Guimaraes S., ArbuckleB.S., PetersJ., AdcockS.E., Buitenhuis H., ChazinH., ManaseryanN., Uerpmann H.-P., GrangeTh., GeiglE.-M. Ancient DNA shows domestic horses were introduced in the southern Caucasus and Anatolia during the Bronze Age // Science Advances. 2020. №6. eabb0030. DOI: 10.1126/sciadv.abb0030

Gürsan-Salzmann A. The New Chronology of the Bronze Age Settlement of Tepe Hissar, Iran. University Museum Monographs 142. Philadelphia: University of Pennsylvania, 2016. $408 \mathrm{p}$.

JansenTh., ForsterP., LevineM.A., OelkeH., Hurles M., Renfrew C., Weber J., OlekK. Mitochondrial DNA and the origins of the domestic horse // PNAS. 2002. № 99(16). P. 10905-10910.

Lafont $B$. Cheval, âne, onagre et mule dans la haute histoire mésopotamienne: quelques données nouvelles // Topoi. Orient-Occident. 2000. Supplément 2. P. 207-221.

Lamberg-Karlovsky C.C. Excavations at Tepe Yahya: Reconstructing the Past // Excavations at Tepe Yahya, Iran. 1967-1975. The Third Millennium / C.C.Lamberg-Karlovsky (ed.). Cambridge, Mass.: Peabody Museum Press, 2001. P. 269-280.

Levine $M$. Domestication and early history of the horse // The domestic horse: The origins, development, and management of its behaviour / D.M.Mills, S.M. McDonnell (eds.). Cambridge: University Press, 2005. P. 5-22.

LibradoP., KhanN., Fages A. et al. The origins and spread of domestic horses from the Western Eurasian steppes // Nature. 2021. P.1-24. DOI: 10.1038/ s41586-021-04018-9.

Lindgren G., BackströmN., SwinburneJ., HellborgL., EinarssonA., SandbergK., CothranG., VilàC., Binns M., Ellegren H. Limited number of patrilines in horse domestication // Nature Genetics. 2004. №36(4). P. 335-336. 
LittauerM.A., CrouwelJ.H. Wheeled Vehicles and Ridden Animals in the Ancient Near East. Leiden: Brill, 1979. $185 \mathrm{p}$.

LittauerM.A., CrouwelJ.H. Kampfwagen // Reallexikon der Assyriologie und vorderasiatische Archäeologie. V / D.O.Edzard (ed.). Berlin-New York: de Gruyter, 1980. P. 336-351.

LittauerM.A., CrouwelJ.H. The Earliest Evidence for Metal Bridle Parts // Oxford Journal of Archaeology. 2001. №20(4). P. 329-338.

MakowskiM. Terracotta Equid Figurines from Tell Arbid. New Evidence on Equids, their Equipment and Exploitation in North Mesopotamia During Third and first half of second millennium BC // Études et Travaux (Institut des Cultures Méditerranéennes et Orientales de l'Académie Polonaise des Sciences). 2014. №27. P. 257-278.

Mashkour M. Equids in the northern part of the Iranian central plateau from the Neolithic to Iron Age: New zoogeographic evidence // Prehistoric steppe adaptation and the horse / M. Levine, C. Renfrew, K. Boyle (eds.). Cambridge: McDonald Institute for Archaeological Research, 2004. P. 129-138.

MichelC. The perdum-mule, a mount for distinguished persons in Mesopotamia during the first half of the second millennium BC // Man and animal in antiquity. Proceedings of the conference at the Swedish Institute in Rome, September 9-12, 2002 / B.S. Frizell (ed.). Rome, 2004. P. 190-200.

MooreyP.R.S. Pictorial Evidence for the History of Horse-Riding in Iraq before the Kassite Period // Iraq. 1970. №32(1). P.36-50.

Moorey P.R.S. The Emergence of the Light, HorseDrawn Chariot in the Near-East c. 2000-1500 B.C. // World Archaeology. 1986. № 18(2). P. 196-215.

MuhlyJ.D. Copper and tin. The distribution of mineral resources and the nature of the metals trade in the Bronze Age. Hamden: Archon Books, 1973. 535 p.
MuhlyJ.D. The Bronze Age Setting // The Coming of the Age of Iron / Th.A. Wertime, J.D. Muhly (eds.), New Haven, London: Yale University Press, 1980. P. 25-68.

Olsen $S$. Early horse domestication: weighing the evidence // Horses and Humans: the Evolution of Human-Equine Relationships / S. Olsen (ed.). Oxford: British Archaeological Reports, 2006. P. 81-113.

PiggottS. Wagon, Chariot and Carriage. New York: Thames and Hudson, 1992. $184 \mathrm{p}$.

Potts D.T. Situating Tepe Yahya in time and space // Excavations at Tepe Yahya, Iran. 1967-1975. The Third Millennium / Lamberg-Karlovsky C.C. (ed.). Cambridge, Mass.: Peabody Museum Press, 2001. P. 195-208.

Taylor W.T.T., Barrón-OrtizCh.I. Rethinking the evidence for early horse domestication at Botai // Scientific Reports. 2021. № 11:7440. P.1-11. DOI: 10.1038/s41598-021-86832-9

ShevE.T. The introduction of the domesticated horse in Southwest Asia // Archaeology, Ethnology and Anthropology of Eurasia. 2016. №44/1. P. 123136. DOI: $10.17746 / 1563-0102.2016 .44 .1 .123-136$

Teufer M. Der Streitwagen: Eine ,indo-iranische“ Erfindung? Zum Problem der Verbindung von Sprachwissenschaft und Archäologie // Archäologische Mitteilungen aus Iran und Turan. 2012. № 44. P. 270-312.

VilaE. Data on Equids from late fourth and third millennium sites in Northern Syria // Equids in Time and Space: Papers in Honour of Vera Eisenmann / M. Mashkour (ed.). Oxford: Oxbow Books, 2006. P. 101-123.

ZarinsJ. The Domesticated Equidae of ThirdMillennium B.C. Mesopotamia // Journal of Cuneiform Studies. 1978. №30(1). P.3-17.

Zarins J., Hauser R. The Domestication of Equidae in Third-Millennium BCE Mesopotamia. CUSAS 24. Bethesda: CDL Press, 2014. 376 p.

\section{REFERENCES}

Avilova, L.I. 2008, "Metal of the Near East. Production models in the Chalcolithic, Early and Middle Bronze Age". Pamyatniki istoricheskoj mysli, Moscow, 227 p. (In Russ.)

Grigoriev, S.A. 2020, "Chronology of the Sintashta and Near Eastern chariots", Magistra Vitae, no. 2, pp. 69-80. doi: 10.24411/2542-0275-2020-0206 (In Russ.)

Epimakhov,A.V., Chechushkov,I.V. 2018, "Ex oriente lux"? Genesis of the chariot in the light of the latest archaeological data", Tomsk State University Journal. History, no. 54, pp. 155-160. doi: 10.17223/19988613/54/25 (In Russ.)

Kalieva, S.S., Logvin, V.N. 2011, "Some notes on the problem of horse domestication of the Tersek and Botai sites", Bulletin of archeology, anthropology and ethnography, no. 2, vol. 15, pp. 246-255. (In Russ.)

Kosintsev, P.A. 2008, "The origin of the "chariot" horses", Proiskhozhdenie i rasprostranenie kolesnichestva, ("The origin and spread of chariots"). Lugansk, pp. 113-129. (In Russ.)
Kotova, N.S. 2013, "The Dereivka culture and sites of the Nizhnemikhailovka type". Maidan, Kiev, Kharkiv, 486 p. (In Russ.)

Kuzmina, E.E. 2000, "The first wave of migration of Indo-Iranians to the south", Journal of Ancient History, no. 4, pp. 3-20. (In Russ.)

Naumov, I.N. 2008, " $\mathrm{C}^{14}$ chronology and factors of the spread of horse domestication skills in Eastern Europe", Proiskhozhdenie i rasprostranenie kolesnichestva, ("The origin and spread of chariots"). Lugansk, pp. 9-19. (In Russ.)

Telegin, D.Y. 1973, "Srednij Stog culture of the Copper Age". Naukova Dumka, Kiev, 187p. (In Ukr.)

Shchetenko,A.Y. 2008, "Time of the appearance of the domestic horse in Central Asia", Proiskhozhdenie i rasprostranenie kolesnichestva, "The origin and spread of chariots"). Lugansk, pp. 219-233. (In Russ.)

Masson, V.M., Merpert, R.M., Munchaev,E.K., Chernysh, E.K. 1982, "Chalcolithic of the USSR". Nauka, Moscow, 359 p. (In Russ.) 
Yudin, A.I. 2008, "Time and place of horse domestication based on the assemblage from Varfolomeevka site in the steppe Trans-Volga region", Proiskhozhdenie i rasprostranenie kolesnichestva, ("The origin and spread of chariots"). Lugansk, pp. 20-29. (In Russ.)

Anthony, D.W. 2007, "The horse, the wheel and language”. University Press, Princeton, $568 \mathrm{p}$.

Anthony, D.W., Brown, D.R., \& George, C. 2006, "Early horseback riding and warfare: the importance of the magpie around the neck", Horses and Humans: The Evolution of the Equine-Human Relationship. British Archaeological Reports, Oxford, pp. 137-156.

Barjamovic, G.A. 2011, "Historical Geography of Anatolia in the Old Assyrian Colony Period". Museum Tusculanum Press, Copenhagen, $537 \mathrm{p}$.

Beja-Pereira,A., England,P.R., \& Ferrand,N., Jordan, S., Bakhiet,A.O., Abdalla, M.A. 2018, "African Origins of the Domestic Donkey", Science, no. 18 , vol.304, issue 5678, pp.1781. doi: $10.1126 /$ science.1096008.

Benecke,N. 2018, "10 Jahre archäogenetische Forschungen zur Domestikation des Pferdes. Die Arbeiten der Jahre bis 2018“, Die e-Forschungsberichte 2018-2 des Deutschen Archäologischen Instituts, pp. 62-70.

Bökönyi, S. 1993, "Pferdedomestikation, Haustierhaltung and Ernährung: archäozoologische Beiträge zu historisch-ethnologischen Problemen". Archaeolingua, Budapest, $61 \mathrm{p}$.

Brownrigg, G. 2006, "Horse control and the bit", Horses and Humans: The Evolution of Equine-Human Relationships, pp.165-171.

Brownrigg, G., Dietz, U.L. 2004， “Schirrung und Zäumung des Streitwagenpferdes: Funktion und Rekonstruktion", Rad und Wagen. Der Ursprung einer Innovation. Wagen im Vorderen Orient und Europa. Beiheft der Archäologische Mitteilungen aus Nordwestdeutschlan. Mainz, pp.481-490.

Czebreszuk, J., Kośko,A., \& Szmyt,M. 2008, "The Horse, Wagon and Roads", Proiskhozhdenie $i$ rasprostranenie kolesnichestva, ("The origin and spread of chariots"). Lugansk, pp. 47-54.

Dercksen, J.G. 2005, "Metals according to documents from Kültepe-Kanish dating to the Old Colony Period", Anatolian Metal III. Abschnitt, Beiheft 18. Bochum, pp. 17-34.

Drews, R. 2017, "Militarism and the Indo-Europeanizing of Europe”. Routledge, London, 296 p.

Edens, C.M., Kohl,P.L. 1993, "Trade and world system in Early Bronze Age Western Asia", Trade and exchange in prehistoric Europe. Oxford, pp. 17-34.

Fages, A. et al. 2019, "Tracking Five Millennia of Horse Management with Extensive Ancient Genome Time Series", Cell, no. 177, pp. 1419-1435. doi: 10.1016/j.cell.2019.03.049.

Gaunitz, C. et al. 2018, "Ancient genomes revisit the ancestry of domestic and Przewalski's horses", Science, no. 06, vol.360, issue 6384, pp. 111-114. doi: 10.1126/science.aao3297.

Greenfield, H.J., Shai,I., \& Greenfield, T.L., Arnold,E.R., Brown,A., Eliyahu,A., Maeir,A.M. 2018, "Earliest evidence for equid bit wear in the an- cient Near East: The "ass" from Early Bronze Age Tell eș-Șâfi/Gath, Israel”, PLoS ONE, no.13, vol.5, e0196335. doi: 10.1371/journal.pone.0196335.

Grigoriev S.A., 2021 "The evolution of antler and bone cheekpieces from the Balkan-Carpathian region to Central Kazakhstan: chronology of "chariot" cultures and Mycenaean Greece", Journal of ancient history and archaeology, no. 8.2, pp.148-189. doi: 10.14795/j.v8i2.633.

Grigson, C. 2012, "Size Matters - Donkeys and Horses in the Prehistory of the Southernmost Levant", Paléorient, no. 38, vol. 1-2, pp. 185-201.

Guimaraes, S., Arbuckle, B.S., \& Peters, J., Adcock, S.E., Buitenhuis, H., Chazin, H., Manaseryan, N., Uerpmann, H.-P., Grange, T., Geigl, E.-M. 2020, “Ancient DNA shows domestic horses were introduced in the southern Caucasus and Anatolia during the Bronze Age", Science Advances, no.6, pp. eabb0030. doi: 10.1126/sciadv.abb0030.

Gürsan-Salzmann,A. 2016, "The New Chronology of the Bronze Age Settlement of Tepe Hissar, Iran. University Museum Monographs 142". University of Pennsylvania, Philadelphia, $408 \mathrm{p}$.

Jansen, T., Forster, P., \& Levine, M.A., Oelke, H., Hurles, M., Renfrew, C., Weber, J., Olek, K. 2002, "Mitochondrial DNA and the origins of the domestic horse", PNAS, no. 99, vol. 16, pp. 10905-10910.

Lafont, B. 2000, "Cheval, âne, onagre et mule dans la haute histoire mésopotamienne: quelques données nouvelles", Topoi. Orient-Occident, part. 2, pp. 207-221.

Lamberg-Karlovsky, C.C. 2001, "Excavations at Tepe Yahya: Reconstructing the Past", Excavations at Tepe Yahya, Iran. 1967-1975. The Third Millennium. Cambridge, pp. 269-280.

Levine, M. 2005, "Domestication and early history of the horse", The domestic horse: The origins, development, and management of its behaviour. Cambridge, pp. 5-22.

Librado,P., Khan, N., \& Fages,A. et al. 2021, "The origins and spread of domestic horses from the Western Eurasian steppes", Nature, pp.1-24. doi: 10.1038/s41586-021-04018-9.

Lindgren, G., Backström, N., \& Swinburne, J., Hellborg, L., Einarsson, A., Sandberg, K., Cothran, G., Vilà, C., Binns, M., Ellegren, H. 2004, "Limited number of patrilines in horse domestication", Nature Genetics, no.36, vol.4, pp.335-336.

Littauer, M.A., Crouwel, J.H. 1979, "Wheeled Vehicles and Ridden Animals in the Ancient Near East". Brill, Leiden, $185 \mathrm{p}$.

Littauer, M.A., Crouwel, J.H. 1980, "Kampfwagen", Reallexikon der Assyriologie und vorderasiatische Archäeologie. V. Berlin-New York, pp.336351.

Littauer, M.A., Crouwel, J.H. 2001, "The Earliest Evidence for Metal Bridle Parts", Oxford Journal of Archaeology, no.20, vol.4, pp.329-338.

Makowski, M. 2014, "Terracotta Equid Figurines from Tell Arbid. New Evidence on Equids, their Equipment and Exploitation in North Mesopotamia During Third and first half of second millennium 
BC", Études et Travaux (Institut des Cultures Méditerranéennes et Orientales de l'Académie Polonaise des Sciences, no 27, pp. 257-278.

Mashkour, M. 2004, "Equids in the northern part of the Iranian central plateau from the Neolithic to Iron Age: New zoogeographic evidence", Prehistoric steppe adaptation and the horse. Cambridge, pp. 129 138.

Michel, C. 2004, "The perdum-mule, a mount for distinguished persons in Mesopotamia during the first half of the second millennium BC", Man and animal in antiquity. Proceedings of the conference at the Swedish Institute in Rome, September 9-12, 2002, pp. 190-200.

Moorey,P.R.S. 1970, "Pictorial Evidence for the History of Horse-Riding in Iraq before the Kassite Period", Iraq, no. 32, vol. 1, pp.36-50.

Moorey,P.R.S. 1986, "The Emergence of the Light, Horse-Drawn Chariot in the Near-East c. 2000-1500 B.C.", World Archaeology, no. 18, vol.2, pp. 196-215.

Muhly, J.D. 1973, "Copper and tin. The distribution of mineral resources and the nature of the metals trade in the Bronze Age". Archon Books, Hamden, $535 \mathrm{p}$.

Muhly,J.D. 1980, "The Bronze Age Setting", The Coming of the Age of Iron. New Haven, London, pp. 25-68.

Olsen, S. 2006, "Early horse domestication: weighing the evidence", Horses and Humans: the
Evolution of Human-Equine Relationships. Oxford, pp. 81-113.

Piggott, S. 1992, "Wagon, Chariot and Carriage". Thames and Hudson, New York. $184 \mathrm{p}$.

Potts, D.T. 2001, "Situating Tepe Yahya in time and space", Excavations at Tepe Yahya, Iran. 19671975. The Third Millennium. Cambridge, pp. 195-208.

Taylor,W.T.T., Barrón-Ortiz, C.I. 2021, "Rethinking the evidence for early horse domestication at Botai", Scientific Reports, no. 11: 7440, pp. 1-11. doi: 10.1038/s41598-021-86832-9.

Shev, E.T. 2016, "The introduction of the domesticated horse in Southwest Asia", Archaeology, Ethnology and Anthropology of Eurasia, no. 44/1, pp. 123136. doi: 10.17746/1563-0110.2016.44.1.123-136.

Teufer, M. 2012, "Der Streitwagen: Eine ,indoiranische" Erfindung? Zum Problem der Verbindung von Sprachwissenschaft und Archäologie", Archäologische Mitteilungen aus Iran und Turan, no.44, pp. 270-312.

Vila, E. 2006, "Data on Equids from late fourth and third millennium sites in Northern Syria", Equids in Time and Space: Papers in Honour of Vera Eisenmann. Oxford, pp. 101-123.

Zarins, J. 1978, "The Domesticated Equidae of Third-Millennium B.C. Mesopotamia", Journal of Cuneiform Studies, no.30, vol. 1, pp.3-17.

Zarins, J., Hauser, R. 2014, "The Domestication of Equidae in Third-Millennium BCE Mesopotamia. CUSAS 24". CDL Press, Bethesda, $376 \mathrm{p}$.

\section{Сведения об авторе}

Григорьев Станислав Аркадьевич, кандидат исторических наук, старший научный сотрудник. Институт истории и археологии УрО РАН, Российская Федерация, г. Челябинск. E-mail: stgrig@mail.ru, ORCID: 0000-0001-6633-8686

\section{Information About the Author}

Stanislav A. Grigoriev, Ph.D., Senior Researcher. Institute of History and Archaeology of the Ural Branch of the RAS, Russian Federation, Chelyabinsk. E-mail: stgrig@mail.ru, ORCID: 0000-0001-6633-8686 